Jurnal DIALOGIKA Manajemen dan Administrasi

Homepage: https://ejurnal.unma.ac.id/index.php/dialogika

Vol. 3 No. 1, Februari 2022, halaman: 21 31

E-ISSN: 2720-9865, P-ISSN: 2716-3563

DOI : https://doi.org/10.31949/dialogika.v3i1.2113

\title{
PENGARUH PERENCANAAN, PENGORGANISASIAN, PELAKSANAAN DAN PENGAWASAN TERHADAP EFEKTIVITAS PELAYANAN RETRIBUSI PERSAMPAHAN DI KABUPATEN MAJALENGKA
}

\author{
Vidi Adhitama1 ${ }^{*}$, Lalan Soeherlan $S^{2}$, Aceng Jarkasih ${ }^{3}$ \\ (1)Mahasiswa Pascasarjana Ilmu Administrasi, Universitas Majalengka, Jawa Barat, Indonesia \\ (2)(3)Dosen Pascasarjana Ilmu Administrasi, Universitas Majalengka, Jawa Barat, Indonesia \\ e-mail korespondensi: -
}

Disubmit Desember 2021 , diterima Januari 2022 , diterbitkan Februari 2022

Submitted December 2021, Accepted January 2022, Published February 2022

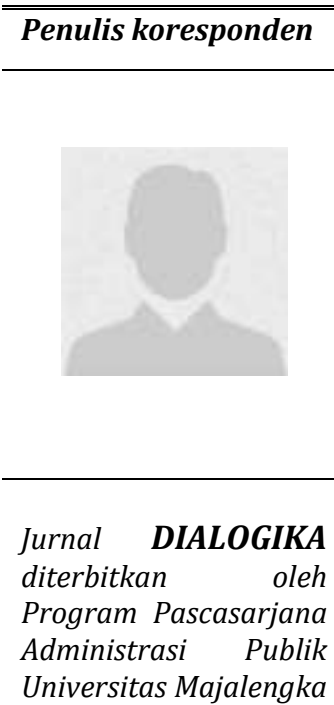
\begin{abstract}
This research aims to analyze management functions including planning, organizing, implementation and supervision of its effect on service effectiveness. This research uses quantitative methods by testing hypotheses from the functions of planning, organizing, implementing and monitoring the effectiveness of services both simultaneously and partially. The sample in this study was employees involved in waste management at the Environment Agency which amounted to 142 using a random sampling system. The results of the study proved that planning, organizing, implementation and supervision have a positive influence on the effectiveness of services both simultaneously and partially.
\end{abstract}

Keywords: Planning; Organization; Implementation; Supervision; Effectiveness. Abstrak

Penelitian ini bertujuan untuk menganalisis fungsi manajemen di antaranya perencanaan, pengorganisasian, pelaksanaan dan pengawasan pengaruhnya terhadap efektivitas pelayanan. Penelitian ini menggunakan metode kuantitatif dengan menguji hipotesis dari fungsi perencanaan, pengorganisasian, pelaksanaan dan pengawasan terhadap efektivitas pelayanan baik secara simultan maupun parsial. Sampel pada penelitian ini adalah pegawai yang terlibat dalam pengelolaan sampah pada Dinas Lingkungan Hidup yang berjumlah sebanyak 142 dengan memakai sistem random sampling. Hasil penelitian membuktikan bahwa perencanaan, pengorganisasian, pelaksanaan dan pengawasan memiliki pengaruh positif terhadap efektivitas pelayanan baik secara simultan maupun parsial.

Kata kunci: Perencanaan; Pengorganisasian; Pelaksanaan; Pengawasan; Efektivitas. (i) This work is licensed under a Creative Commons Attribution 4.0 International License

\section{PENDAHULUAN}

Pelayanan publik merupakan satu aspek yang penting dalam kehidupan negara serta wujud dari upaya negara dalam memenuhi kepentingan masyarakat. Dalam ruang lingkup ilmu administrasi negara pelayanan publik muncul karena adanya kepentingan publik, pemerintah selaku pemegang amanat pemerintahan diharuskan menyusun suatu organisasi tata pemerintahan yang mengacu pada pola pelayanan publik yang memuaskan masyarakat dengan mengedepankan efisensi dan efektivitas. Definisi pelayanan publik menurut Kepmen PAN Nomor 25 Tahun 2004 adalah segala kegiatan pelayanan yang dilaksanakan oleh penyelenggara pelayanan publik sebagai upaya pemenuhan kebutuhan penerima layanan, maupun dalam rangka pelaksanaan ketentuan peraturan perundang-undangan.

Salah satu bentuk pelayanan publik adalah pelayanan kebersihan. 
Undangundang Nomor 18 Tahun 2008 pasal 11 tentang Pengelolaan Sampah menjelaskan bahwa setiap orang berhak mendapatkan pelayanan dalam pengelolaan sampah secara baik dan berwawasan lingkungan dari Pemerintah, Pemerintah Daerah, atau pihak lain yang diberi tanggung jawab untuk itu. Artinya bahwa setiap masyarakat mempunyai hak untuk mendapatkan pelayanan kebersihan. Kebersihan merupakan hal utama yang harus diperhatikan oleh pemerintah maupun masyarakat di setiap kota karena kebersihan merupakan cerminan keindahan dari sebuah kota. Oleh sebab itu, pemerintah kota perlu menangani secara serius persoalan kebersihan khususnya penanganan masalah sampah. Permasalahan sampah tidak pernah ada habisnya dan menjadi persoalan serius terutama di kota-kota besar di Indonesia. Kabupaten Majalengka salah satu kabupaten yang ada di Provinsi Jawa Barat mempunyai wilayah seluas $1.204,24 \mathrm{~km}^{2}$ yang terbagi ke dalam 26 kecamatan dan 343 desa. Berkenaan dengan bertambahnya penduduk dikaitkan dengan tata ruang yang terbatas artinya penduduk kian bertambah namun keadaan ruang tetap. Keadaan ruang yang tetap jelas harus menampung sisa-sisa kegiatan yang dilakukan setiap harinya oleh penduduk yaitu sampah.

Dampak yang terjadi dengan pertambahan jumlah penduduk sering menimbulkan permasalahan, seperti bertambahnya jumlah sampah yang dihasilkan oleh masyarakat tersebut. Jadi disini terdapat hubungan, yakni antara jumlah penduduk wilayah yang tetap dan sampah yang diproduksi oleh masyarakat, akibatnya beban lingkungan akan semakin berat. Setiap aktivitas yang dilakukan masyarakat biasanya menyisakan sampah, misalnya mengonsumsi makanan ringan yang menyisakan sampah plastik. Begitu juga aktivitas memasak pada setiap rumah tangga yang dilakukan setiap harinya dan aktivitas industri. Setiap harinya para petugas kebersihan harus ekstra bekerja keras menyisir sampah di setiap tempat dan mengangkutnya hingga ke tempat pembuangan akhir.

Pengelolaan persampahan di Kabupaten Majalengka dikelola oleh Dinas Lingkungan Hidup berdasarkan Peraturan
Daerah Kabupaten Majalengka Nomor 10 Tahun 2009 Dinas tersebut memiliki tugas tidak hanya melakukan pengelolaan sampah dan upaya pengurangan sampah, sebagai organisasi inti dalam pengelolaan sampah juga harus melakukan koordinasi antar lembaga.

Dinas Lingkungan Hidup Kabupaten Majalengka sebagai salah satu instansi pemerintah bertugas menyelenggarakan pengelolaan sampah, tata kebersihan dan pertamanan keindahan kota menjadi ujung tombak terdepan dalam mengatasi permasalahan tersebut di atas. Manajerial organisasi yang baik akan melahirkan sumber daya manusia yang profesional dalam menjalankan tugas dan fungsinya, responsivitas atau kepekaan terhadap kebersihan lingkungan sekitar, inovasi pemikiran dan tindakan solusi akan muncul manakala adanya rasa tanggungjawab. Sebagai bentuk kesadaran masyarakat, pengelolaan sampah yang dilakukan oleh pemerintah masyarakat diwajibkan membayar retribusi sebagai bentuk pengelolaan persampahan agar pelaksanaan pelayanan sampah kepada masyarakat dilaksanakan secara professional. Retribusi ini menjadi salah satu sumber penerimaan Negara yang signifikan. Berbeda dengan pajak, retribusi pada umumnya berhubungan dengan kontra prestasi langsung, dalam arti bahwa pembayar retribusi akan menerima imbalan secara langsung dari retribusi yang dibayarnya. Hal tersebut memang disengaja sebab pembayaran tersebut oleh si pembayar ditujukan semata-mata untuk mendapatkan suatu prestasi tertentu dari pemerintah, misalnya pembayaran uang sekolah/kuliah, pembayaran abonemen air minum, pembayaran listrik, pembayaran gas, dan sebagainya. Oleh sebab itu, dapat didefenisikan bahwa retribusi adalah pungutan sebagai pembayaran atas jasa

atau pemberian izin tertentu yang khusus disediakan atau diberikan oleh pemerintah untuk kepentingan orang pribadi atau badan.

Pemberian kewenangan kepada daerah untuk memungut pajak dan retribusi daerah telah mengakibatkan pemungutan berbagai jenis pajak dan retribusi daerah berkaitan dengan berbagai aspek kehidupan 
masyarakat. Pemungutan ini harus dapat dipahami oleh masyarakat sebagai sumber penerimaan yang dibutuhkan oleh daerah untuk meningkatkan kesejahteraan masyarakat di daerah. Seperti halnya pajak daerah, retribusi daerah dilaksanakan berdasarkan Undang-undang Nomor 28 Tahun 2009 tentang Pajak Daerah Dan Retribusi Daerah dan Peraturan Pemerintah Nomor 66 Tahun 2001 tentang peraturan Umum Retribusi Daerah dan Undang-undang Nomor 12 Tahun 2008 tentang pokok-pokok Pemerintahan di Daerah, selanjutnya untuk pelaksanaannya di masing-masing daerah, pungutan retribusi daerah dijabarkan dalam bentuk peraturan daerah yang mengacu kepada peraturan perundang-undangan yang berlaku. Undang-undang ini menjadi dasar hukum pemungutan pajak dan retribusi daerah dewasa ini yang memberikan kewenangan kepada daerah untuk memungut atau tidak memungut suatu jenis pajak atau retribusi pada daerahnya.

Pendapatan Asli Daerah (PAD) merupakan sumber penerimaan daerah yang berasal dari beberapa hasil penerimaan daerah dan salah satunya diperoleh dari penerimaan retribusi daerah. Hasil retribusi daerah perlu diusahakan agar menjadi pemasukan yang potensial terhadap PAD. Dari penerimaan sektor retribusi daerah diharapkan dapat mendukung sumber pembiayaan daerah dalam menyelenggarakan pembangunan daerah, sehingga akan meningkatkan dan memeratakan perekonomian serta kesejahteraan masyarakat di daerahnya. Upaya peningkatan PAD dapat dilakukan salah satunya dengan meningkatkan sumber daya dan sarana yang terbatas serta meningkatkan pemungutan yaitu dengan mengoptimalkan potensi yang ada, serta terus mengupayakan menggali sumbersumber pendapatan baru yang potensinya memungkinkan, sehingga dapat di pungut pajak atau retribusinya sesuai ketentuan yang ada.

Retribusi daerah yang merupakan pembayaran atas jasa atau pemberian izin khusus yang disediakan atau diberikan oleh pemerintah daerah kepada pribadi/badan, diharapkan dapat mendukung sumber pembiayaan daerah dalam menyelenggarakan pembangunan daerah, sehingga akan meningkatkan dan memeratakan perekonomian serta kesejahteraan masyarakat di daerahnya. Beberapa faktor yang menyebabkan sektor retribusi daerah menjadi potensial sebagai sumber keuangan daerah dari pada sumbersumber lainnya, antara lain:

1. Retribusi dapat meningkatkan Pendapatan Asli Daerah (PAD) dalam hal membiayai penyelenggaraan pemerintahan dan pembangunan daerah. Retribusi daerah dipungut atas balas jasa sehingga pembayarannya dapat dilakukan berulang kali.

2. Pelaksanaan pemungutan retribusi dapat dilakukan di luar waktu yang telah ditentukan oleh petugas perundangundangan selama pemerintah daerah dapat menyediakan jasa dengan persetujuan pemerintah pusat.

3. Sektor retribusi terkait erat oleh tingkat aktivitas sosial ekonomi masyarakat disuatu daerah.

Dalam upaya meningkatkan Pendapatan Asli Daerah untuk membiayai pelaksanaan pembangunan di Kabupaten Majalengka, pemerintah telah melaksanakan berbagai bentuk retribusi daerah, salah satu bentuk retribusi daerah tersebut adalah mengenai retribusi persampahan yang di atur dalam Peraturan Daerah Kabupaten Majalengka Nomor 13 Tahun 2010 Tentang Retribusi Pelayanan Persampahan/Kebersihan di Kabupaten Majalengka. Dengan adanya berbagai macam retribusi, maka jelaslah bahwa retribusi pelayanan persampahan merupakan salah satu Pendapatan Asli Daerah Kabupaten Majalengka yang potensial diantara sekian banyak retribusi yang ada.

Banyaknya jumlah penduduk di Kabupaten Majalengka sebanyak 1.193.722 jiwa dengan laju pertumbuhan pertahunnya sebesar 1,56 persen dan kepadata penduduk sebanyak 971 orang per km2 (BPS Majalengka, 2018), hal tersebut dapat menimbulkan peluang berbagai masalah di tengah masyarakat. Salah satunya adalah masalah persampahan yang terdiri dari berbagai jenis seperti sampah kering dan sampah basah. Kondisi tersebut memperlihatkan bahwa potensi sampah di Kabupaten Majalengka cukup besar seiring 
dengan laju pertumbuhan penduduk yang sangat pesat. Maka dari itu pemerintah melakukan suatu kebijakan dalam hal ini pemungutan retribusi persampahan yang dilakukan oleh Dinas Lingkungan Hidup Kabupaten Majalengka. Retribusi itu sendiri dipungut dengan menggunakan SKRD (Surat Ketetapan Retribusi Daerah) atau dokumen lain yang dipersamakan. Pemungutan retribusi ini cukup efektif dalam meningkatkan kebersihan lingkungan dan menunjang Pendapatan Daerah. Yang menjadi indikasi masalah penelitian dalam retribusi sampah ini yaitu, masih banyak masyarakat khususnya di Kabupaten Majalengka yang tidak mengetahui tentang peraturan daerah retribusi persampahan sehingga pelaksanaannya tidak efektif, serta masyarakat merasa pelayanan yang dilakukan oleh pihak yang bertugas tidak memuaskan sehingga kemauan untuk membayar tidak ada. Dengan adanya masalah tersebut tentu membawa pengaruh terhadap peningkatan retribusi persampahan Kabupaten Majalengka. Oleh sebab itu, pemerintah perlu memikirkan hal ini secara serius serta berusaha melakukan upaya pengoptimalan peningkatan penerimaan retribusi persampahan, sehingga dapat memberi kontribusi yang maksimal dalam meningkatkan retribusi daerah secara khusus dan Pendapatan Asli Daerah secara umum.

Dengan demikian perlu adanya perhatian dari semua pihak baik unsur pemerintah maupun masyarakat sebagai wajib retribusi dalam menyikapi bagaimana melakukan pengelolaan retribusi persampahan yang ada sehingga betul-betul dapat memberikan kontribusi terhadap peningkatan Pendapatan Asli Daerah. Sebagaimana pengelolaan retribusi persampahan tidak terlepas dari fungsi manajemen, maka perlu ditunjang dengan manajemen secara optimal, karena manajemen dibutuhkan oleh organisasi dalam mencapai tujuan.

\section{METODE PENELITIAN}

Metode penelitian merupakan prosedur dan cara melakukan pengolahan data yang diperlukan untuk menjawab atau memecahkan masalah penelitian termasuk pengujian hipotesis sehingga memudahkan pembuatan kesimpulan. Sugiyono (2010:20) menyatakan bahwa : Metode penelitian dapat diartikan sebagai cara ilmiah yang dilakukan untuk mendapatkan data yang obyektif, valid dan reliable dengan tujuan dapat ditemukan, dibuktikan dan dikembangkan suatu pengetahuan sehingga pada gilirannya dapat digunakan untuk memahami, memecahkan dan mengantisipasi masalah. Berdasarkan variabel-variabel yang diteliti, maka penelitian ini bersifat deskriptif dan verifikatif. Penelitian deskrptif merupakan penelitian yang bertujuan untuk memberikan gambaran dari variabel penelitian, sedangkan penelitian verifikatif bertujuan untuk mengecek kebenaran hasil penelitian.

Berdasarkan hal tersebut di atas, secara deskriptif penelitian ini bertujuan untuk memperoleh ciri-ciri variabel yang diteliti yaitu perencanaan, pengorganisasian, pelaksanaan, pengawasan dan efektivitas pelayanan. Secara verifikatif, penelitian ini bertrujuan untuk mengadakan penelitian sekaligus pengujian kebenaran dari hipotesis yang didasarkan pada data penelitian di lapangan di mana penelitian ini akan diuji. Adapun permasalahan yang akan diuji adalah mengenai pengaruh yang diberikan dari perencanaan, pengorganisasian, pelaksanaan dan pengawasan terhadap efektivitas pelayanan secara parsial maupun simultan. Dilihat dari jenis penelitiannya yaitu penelitian deskriptif dan verifikatif, akan metode yang digunakan dalam penelitian ini adalah explanatory survey.

Metode explanatory survey digunakan untuk memprediksi dan menjelaskan hubungan atau pengaruh dari suatu variabel ke variabel lainnya. Metode ini mengemukakan fakta-fakta yang didukung oleh penyebaran angket kepada responden serta pemahaman literatur. Penelitian ini dilakukan dalam kurun waktu kurang dari satu tahun, sehinga metode yang digunakan adalah cross sectional method, yaitu "metode penelitian dengan cara memperbaiki objek dalam kurun waktu tertentu atau tidak berkesinambunan dalam jangka waktu yang panjang" (Husain Umar, 2001:45).

Sampel pada penelitian ini sebanyak 142 orang yang bekerja pada bidang 
pengelolaan sampah. Teknik pengumpulan data mengacu pada media apa yang digunakan peneliti dalam memperoleh data. Dalam penelitian ini data yang diperoleh adalah data primer, yaitu data diperoleh langsung dari responden dan data sekunder yang tidak langsung diperoleh dari objek yang bersangkutan. Teknik analisis yang digunakan adalah Analisis jalur (path analysis) bertujuan untuk menentukan besarnya pengaruh suatu variabel terhadap variabel lainnya, baik itu pengaruh yang sifatnya secara langsung maupun tidak langsung, serta mengukur besarnya pengaruh dari suatu variabel penyebab ke variabel akibat yang disebut dengan koefisien jalur.

\section{HASIL DAN PEMBAHASAN}

Teknik analisis jalur (path analysis), analisis ini akan digunakan dalam menguji besarnya kontribusi yang ditunjukkan oleh koefisien jalur pada setiap diagram jalur dari hubungan kausal antar variable X1, X2, X3 dan X4 terhadap Y. Untuk mengetahui derajat hubungan antar variabel perencanaan (X1), pengorganisasian (X2), pelaksanaan (X3) dan pengawasan (X4) terhadap efektivitas pelayanan persampahan (Y) dilakukan penyebaran kuesioner yang bersifat tertutup dan analisis digunakan teknik korelasi merupakan dasar perhitungan dari koefisien jalur. Kemudahan dalam perhitungan digunakan jasa komputer berupa software dengan program SPSS Windows Version 20.0. Adapun hipotesis yang digunakan dalam penelitian ini adalah sebagai berikut :

1. Perencanaan, pengorganisasian, pelaksanaan dan pengawasan berkontribusi secara simultan dan signifikan terhadap efektivitas pelayanan retribusi sampah di Kabupaten Majalengka.

2. Perencanaan, pengorganisasian, pelaksanaan dan pengawasan tidak berkontribusi secara simultan dan signifikan terhadap efektivitas pelayanan retribusi sampah di Kabupaten Majalengka

Kerangka hubungan kausal empiris jalur dapat dilihat melalui persamaan struktur sebagai berikut :

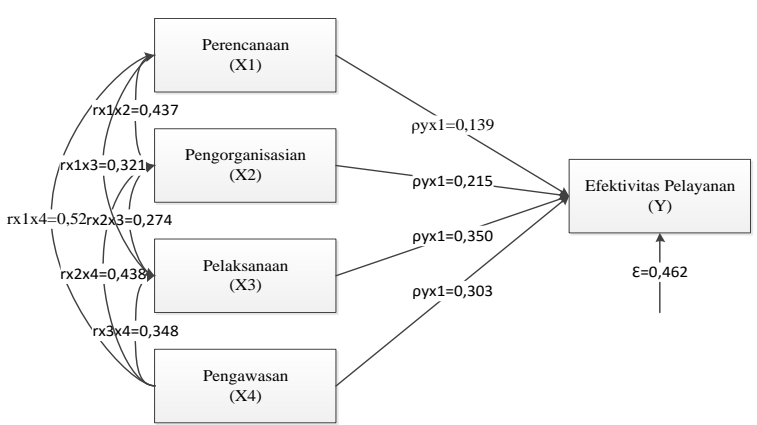

Gambar 1. Hubungan Struktur Variabel $\mathrm{X} 1, \mathrm{X} 2, \mathrm{X} 3, \mathrm{X} 4$ terhadap $\mathrm{Y}$

Kerangka hubungan kausal empiris jalur (X1 terhadap Y, X2 terhadap Y, X3 terhadap Y dan X4 terhadap Y) dapat dibuat melalui persamaan struktural sebagai berikut. $Y=\rho_{y \chi 1} X_{1}+\rho_{y \chi 2} X_{2}+\rho_{y \chi 3} X_{3}+\rho_{y \chi 4} X_{4}+\rho_{y} \varepsilon$
$Y=0,139 X_{1}+0,215 X_{2}+0,350 X_{3}+0,303 X_{4}+0,462 \varepsilon$

Proses dan hasil pengujian hipotesis penelitian dengan menggunakan program SPSS 20.0 adalah sebagai berikut :

Tabel 1. Model 1 Correlation

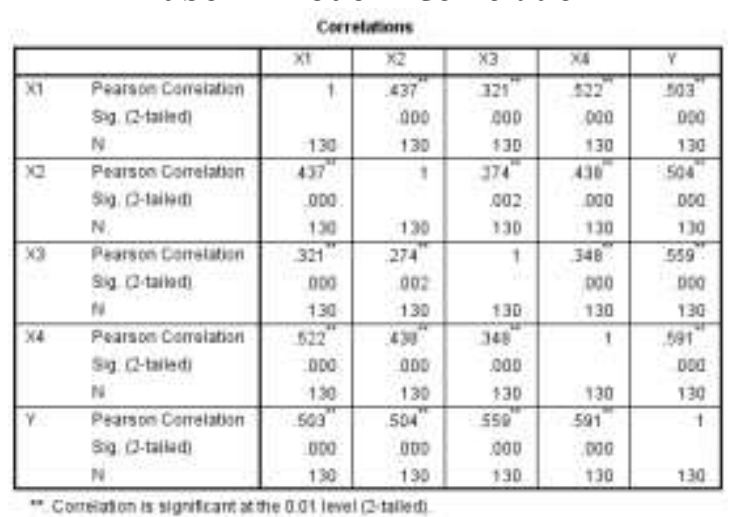

Tabel 2. Model 1 Summary

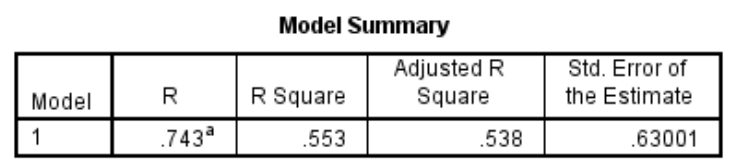

a. Predictors: (Constant), $\mathrm{X} 4, \mathrm{X} 3, \mathrm{X} 2, \mathrm{X} 1$

Tabel 3. Model 1 ANOVA

nмova"

\begin{tabular}{|c|c|c|c|c|c|c|}
\hline \multicolumn{2}{|c|}{ Mods 1} & $\begin{array}{l}\text { Sam of } \\
\text { squares }\end{array}$ & at & Mean Squart & $F$ & Sig. \\
\hline \multirow[t]{3}{*}{1} & Regresseon & 61.36 & 4 & 15.326 & 38.621 & $600^{\circ}$ \\
\hline & Resaidal & 49.614 & 125 & 397 & & \\
\hline & Total & $1 \pm 0231$ & 129 & & & \\
\hline
\end{tabular}


Tabel 4. Model 1 Coefficients

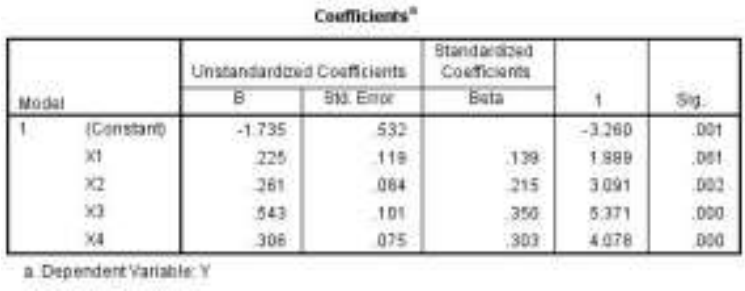

Dari hasil pengolahan data program SPSS 20.0 di atas, tampak bahwa tabel Correlation, Model Summary, Anova dan Coefficient ditunjukkan oleh Standardized Coefficients (Beta), sedang Unstandarized Coefficients, merupakan koefisien regresi biasa. Berdasarkan hasil pengolahan data (Tabel 4 sampai tabel 7.), koefisien jalur yang diperoleh diuji sebagai berikut :

Uji kseluruhan ditunjukkan oleh tabel hipotesis statistik dirumuskan sebagai berikut :

$$
\begin{aligned}
& \text { Ha: } \rho_{y x 4=} \rho_{y x 2=} \rho_{y x 3=} \rho_{y x 4 \neq 0} \\
& \text { Ho }: \rho_{y x 4=} \rho_{y x 2=} \rho_{y x 3=} \rho_{y x 4 \neq 0}
\end{aligned}
$$

Hipotesis bentuk kalimat sebagai berikut :

Ha : Perencanaan, pengorganisasian, pelaksanaan dan pengawasan berkontribusi secara simultan dan signifikan terhadap efektivitas pelayanan retribusi sampah di Kabupaten Majalengka.

Ho : Perencanaan, pengorganisasian, pelaksanaan dan pengawasan tidak berkontribusi secara simultan dan signifikan terhadap efektivitas pelayanan retribusi sampah di Kabupaten Majalengka

Uji signifikansi analisis jalur dengan perbandingan antara nilai probabilitas 0,05 dengan nilai probabilitas Sig dengan dasar pengambilan keputusan sebagai berikut :

1) Jika nilai probabilitas 0,05 lebih kecil atau sama dengan nilai probabilitas Sig atau $[0,05 \leq$ Sig], maka Ho diterima dan $\mathrm{Ha}$ ditolak, artinya tidak signifikan

2) Jika nilai probabilitas 0,05 lebih besar atau sama dengan nilai probabilitas Sig atau $[0,05 \geq$ Sig], maka Ho ditolak dan Ha diterima, artinya signifikan

Dari persamaan struktur hasil analisis tabel summary juga tampak koefisien dterminasi $\left(\mathrm{R}^{2}\right)$ sebesar 0.553 berarti bahwa $55,30 \%$ variabelitas variabel $Y$ yaitu efektivitas pelayanan retribusi persampahan dapat diterangkan oleh variabel bebas dalam hal ini perencanaan (X1), pengorganisasian (X2), pelaksanaan (X3) dan pengawasan (X4). Artinya dapat disimpulkan bahwa terdapat hubungan secara linier antara perencanaan (X1), pengorganisasian (X2), pelaksanaan (X3) dan pengawasan (X4) dengan efektivitas pelayanan retribusi persampahan (Y). Yang dapat diartikan bahwa terdapat pengaruh secara bersamasama antara perencanaan, pengorganisasian, pelaksanaan dan pengawasan terhadap efektivitas pelayanan retribusi persampahan sebesar determinasinya $\left(\mathrm{R}^{2}\right)=0.553$ atau $55,30 \%$, atau juga dapat diartikan bahwa pengaruh variabel-variabel diluar model termasuk golongan lemah yaitu 0.462 (error).

Hasil ini mengindikasikan bahwa pelayanan retribusi persampahan di Kabupaten Majalengka tidak hanya ditentukan oleh manajemen pengelolaan persampahan tetapi masih banyak faktor lainnya yang turut berpengaruh dalam pelayanan retribusi persampahan yang efektif.

Dari tabel anova di atas juga diperoleh nilai $F$ sebesar 38,621 dengan nilai probabilitas $(s i g)=0,000$. karena nilai sig $\leq$ 0,05 , maka keputusannya adalah Ho ditolak dan oleh sebab itu, pengujian secara individual dapat dilakukan. Untuk menguji secara parsial (sendiri-sendiri) atau untuk mengetahui variabel bebas mana yang berpengaruh signifikan terhadap variabel terikat yang diuji dengan uji $\mathrm{t}$ berdasarkan tabel 4. di atas. Coefficients(a).

\section{Perencanaan $\left(X_{1}\right)$ berkontribusi secara signifikan terhadap Efektivitas} Pelayanan Retribusi Persampahan (Y)

Uji secara individual ditunjukkan oleh Tabel 4. di atas Coefficients Model 1 di atas. Hipotesis penelitian yang akan diuji dirumuskan menjadi hipotesis statistik adalah sebagai berikut :

Ha : $\rho$ y $\mathrm{x} 1>0$

Ho: $\rho$ y $1=0$

Hipotesis bentuk kalimat

Ha :Perencanaan berkontribusi secara signifikan terhadap efektivitas pelayanan retribusi persampahan 
Ho : Perencanaan tidak berkontribusi secara signifikan terhadap efektivitas pelayanan retribusi persampahan

Secara individual uji statistik yang digunakan adalah uji t yang dihitung dengan rumus :

$$
t_{x 1=} \frac{\rho x 1}{S e \rho x 1}=\frac{0.139}{0.119}=1,168
$$

Selanjutnya untuk mengetahui signifikansi analisis jalur bandingkan antara nilai probablitas 0.05 dengan nilai probabilitas sig dengan dasar pengambilan keputusan sebagai berikut :

1. Jika nilai probabilitas 0.05 lebih kecil atau sama dengan nilai probabilitas sig atau ( $0.05 \leq$ sig), maka Ho diterima Ha ditolak, artinya tidak signifikan

2. Jika nilai probabilitas 0.05 lebih besar atau sama dengan nilai probabilitas sig atau (0.05 $\geq$ sig), maka Ho ditolak dan $\mathrm{Ha}$ diterima, artinya signifikan

Keputusannya terlihat bahwa pada kolom sig (signifikan) pada tabel Coefficients Model 1 didapat nilai sig. 0.061 lebih besar dari nilai probabilitas 0.05 atau nilai $0.05<$ 0.061, maka Ho diterima dan Ha ditolak artinya koefisien analisis jalur tidak signifikan. Jadi, perencanaan tidak berkontribusi secara signifikan terhadap efektivitas pelayanan retribusi persampahan.

2. Pengorganisasian $\left(X_{2}\right)$ Berkontribusi secara signifikan terhadap Efektivitas pelayanan retribusi persampahan

Uji secara individual ditunjukkan oleh

Tabel 4. Coefficients Model 1 di atas. Hipotesis penelitian yang akan diuji dirumuskan menjadi hipotesis statistik adalah sebagai berikut :

Ha: $\rho$ y $\mathrm{x} 2>0$

Ho: $\rho$ y $2=0$

Hipotesis bentuk kalimat

Ha : Pengorganisasian berkontribusi secara signifikan terhadap efektivitas pelayanan retribusi persampahan

Ho : Pengorganisasian tidak berkontribusi secara signifikan terhadap efektivitas pelayanan retribusi persampahan

Secara individual uji statistik yang digunakan adalah uji t yang dihitung dengan rumus : $t_{x 2=} \frac{\rho x 2}{\text { Se } \rho x 2}=\frac{0.215}{0.084}=2,559$

Selanjutnya untuk mengetahui signifikansi analisis jalur bandingkan antara nilai probablitas 0.05 dengan nilai probabilitas sig dengan dasar pengambilan keputusan sebagai berikut :

1. Jika nilai probabilitas 0.05 lebih kecil atau sama dengan nilai probabilitas sig atau ( $0.05 \leq$ sig), maka Ho diterima Ha ditolak, artinya tidak signifikan

2. Jika nilai probabilitas 0.05 lebih besar atau sama dengan nilai probabilitas sig atau $(0.05 \geq \operatorname{sig})$, maka Ho ditolak dan $\mathrm{Ha}$ diterima, artinya signifikan

Keputusannya terlihat bahwa pada kolom sig (signifikan) pada tabel 4. Coefficients Model 1 didapat nilai sig. 0.002 lebih kecil dari nilai probabilitas 0.05 atau nilai $0.05>0.002$, maka Ho ditolak dan $\mathrm{Ha}$ ditrima artinya koefisien analisis jalur signifikan. Jadi, pengorganisasian berkontribusi secara signifikan terhadap efektivitas pelayanan retribusi persampahan.

\section{Pelaksanaan $\left(X_{3}\right)$ berkontribusi secara signifikan terhadap efektivitas pelayanan retribusi persampahan}

Uji secara individual ditunjukkan oleh Tabel 4. Coefficients Model 1 Hipotesis penelitian yang akan diuji dirumuskan menjadi hipotesis statistik berikut :

Ha : $\rho$ у х3 $>0$

Ho : $\rho$ y x $3=0$

Hipotesis bentuk kalimat

$\mathrm{Ha}$ : Pelaksanaan berkontribusi secara signifikan terhadap efektivitas pelayanan retribusi persampahan

Ho : Pelaksanaan tidak berkontribusi secara signifikan terhadap efektivitas pelayanan retribusi persampahan

Secara individual uji statistik yang digunakan adalah uji t yang dihitung dengan rumus :

$t_{x 1=} \frac{\rho x 1}{S e \rho x 1}=\frac{0.350}{0.101}=3,465$

Selanjutnya untuk mengetahui signifikansi analisis jalur bandingkan antara nilai probablitas 0.05 dengan nilai probabilitas sig dengan dasar pengambilan keputusan sebagai berikut : 
1. Jika nilai probabilitas 0.05 lebih kecil atau sama dengan nilai probabilitas sig atau ( $0.05 \leq$ sig), maka Ho diterima Ha ditolak, artinya tidak signifikan

2. Jika nilai probabilitas 0.05 lebih besar atau sama dengan nilai probabilitas sig atau ( $0.05 \geq \operatorname{sig})$, maka Ho ditolak dan Ha diterima, artinya signifikan

Keputusannya terlihat bahwa pada kolom sig (signifikan) pada tabel 4 . Coefficients Model 1 didapat nilai sig. 0.000 lebih kecil dari nilai probabilitas 0.05 atau nilai $0.05>0.000$, maka Ho ditolak dan $\mathrm{Ha}$ diterima artinya koefisien analisis jalur signifikan. Jadi, pelaksanaan merupakan variabel yang memiliki kotribusi tertinggi bila dibandingkan dengan variabel lainnya. Adapun besaran kontribusi pelaksanaan terhadap efektivitas pelayanan retribusi persampahan. Besarnya kontribusi pelaksanaan (X3) yang secara langsung mempengaruhi efektivitas pelayanan retribusi persampahan $(\mathrm{Y})$ adalah $0.350^{2} \mathrm{x}$ $100 \%=12,25 \%$.

\section{Pengawasan $\left(X_{4}\right)$ berkontribusi secara signifikan terhadap efektivitas pelayanan retribusi persampahan}

Uji secara individual ditunjukkan oleh Tabel 4. Coefficients Model 1 Hipotesis penelitian yang akan diuji dirumuskan menjadi hipotesis statistik berikut :

Ha : $\rho$ y $44>0$

Ho : $\rho$ y $4=0$

Hipotesis bentuk kalimat

$\mathrm{Ha}$ : pengawasan berkontribusi secara signifikan terhadap efektivitas pelayanan retribusi persampahan

Ho : pengawasan tidak berkontribusi secara signifikan terhadap efektivitas pelayanan retribusi persampahan

Secara individual uji statistik yang digunakan adalah uji t yang dihitung dengan rumus :

$t_{x 1=} \frac{\rho x 1}{\text { Se } \rho x 1}=\frac{0.303}{0.075}=4,04$

Selanjutnya untuk mengetahui signifikansi analisis jalur bandingkan antara nilai probablitas 0.05 dengan nilai probabilitas sig dengan dasar pengambilan keputusan sebagai berikut :

1. Jika nilai probabilitas 0.05 lebih kecil atau sama dengan nilai probabilitas sig atau
( $0.05 \leq \mathrm{sig})$, maka Ho diterima Ha ditolak, artinya tidak signifikan

2. Jika nilai probabilitas 0.05 lebih besar atau sama dengan nilai probabilitas sig atau ( $0.05 \geq \operatorname{sig})$, maka Ho ditolak dan $\mathrm{Ha}$ diterima, artinya signifikan

Keputusannya terlihat bahwa pada kolom sig (signifikan) pada tabel 4 . Coefficients Model 1 didapat nilai sig. 0.000 lebih kecil dari nilai probabilitas 0.05 atau nilai $0.05>0.000$, maka Ho ditolak dan $\mathrm{Ha}$ diterima artinya koefisien analisis jalur signifikan. Jadi, pengawasan berkontribusi secara signifikan terhadap efektivitas pelayanan retribusi persampahan.

Hasil analisis membuktikan bahwa ada koefisien jalur yang tidak signifikan yaitu variabel perencanaan (X1), maka Model 1 perlu diperbaiki melalui metode trimming, yaitu mengeluarkan perencanaan (X1) yang dianggap hasil dari koefisien jalur tidak signifikan dari analisisnya. Kemudian diulang atau diuji lagi yang mana variabel eksogen perencanaan (X1) tidak diikutsertakan. Hasil perhitungan sebagai berikut :

Tabel 5. Anova Model 2 X2, X3 dan X4 terhadap Y

\begin{tabular}{|c|c|c|c|c|c|c|}
\hline \multicolumn{7}{|c|}{ ANOWh" } \\
\hline & & $\begin{array}{l}\text { Sum of } \\
\text { Sosuarss }\end{array}$ & ar & Masn Square & $F$ & Sig \\
\hline \multirow[t]{3}{*}{$t$} & Fagrassion & 69.900 & 3 & \multirow{3}{*}{$\begin{array}{r}+9.987 \\
.05\end{array}$} & \multirow[t]{3}{*}{45300} & \multirow[t]{3}{*}{$000^{\circ 1}$} \\
\hline & Fessisual & 51030 & 126 & & & \\
\hline & Tota & 110931 & 129 & & & \\
\hline
\end{tabular}

Tabel 6. Coefficients Model 2 X1, X2 dan X4 terhadap Y

coeffacients"

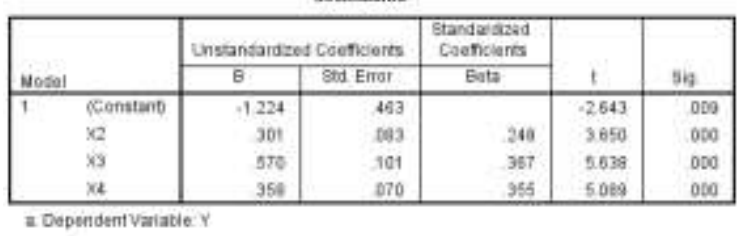

Tabel 7. Model 2 : Summary X1, X2 dan X4 terhadap Y

Model Summary

\begin{tabular}{|l|c|c|c|r|}
\hline Model & R & R Square & $\begin{array}{c}\text { Adjusted R } \\
\text { Square }\end{array}$ & $\begin{array}{c}\text { Std. Error of } \\
\text { the Estimate }\end{array}$ \\
\hline 1 & $.735^{\text {a }}$ & .540 & .529 & .63640 \\
\hline
\end{tabular}

a. Predictors: (Constant) $\times 4, \times 3, \times 2$ 
Berdasarkan hasil analisis jalur (X2, X3, X4 dan Y) yang terlihat pada tabel 4.19 Coefficients Model 2 masing-masing diperoleh nilai :

1. $\rho \mathrm{yx} 2=$ Beta $=0.248[\mathrm{t}=3,650$ dan probabilitas (sig) $=0.000]$

2. $\rho \mathrm{yx} 3=$ Beta $=0.367[\mathrm{t}=5,638$ dan probabilitas (sig) $=0.000]$

3. $\rho \mathrm{yx} 4=$ Beta $=0.355[\mathrm{t}=5.089$ dan probabilitas $(\operatorname{sig})=0.000]$

Besarnya koefisien determinan (kontribusi) $\mathrm{X}_{2}, \mathrm{X} 3$ dan $\mathrm{X} 4$ secara simultan terhadap $Y$ sebesar 0,540 atau sebesar $54,0 \%$, artinya bahwa pengorganisasian, pelaksanaan dan pengawasan berpengaruh secara signifikan terhadap efektivitas pengelolaan persampahan, sementara sisanya sebesar $36,0 \%$ dipengaruhi oleh variabel diluar penelitian. Dengan demikian didapat diagram jalur struktur mengalami perubahan, yaitu menjadi gambar 4. sebagai berikut.

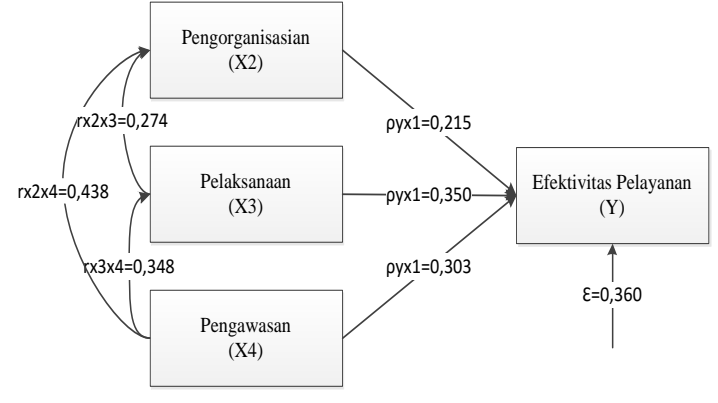

Gambar 2. Hubungan Kausal Empiris Struktur variabel X2, X3 dan X4 terhadap Y

Hasil dari koefisien jalur pada struktur berubah menjadi persamaan struktur yaitu : $\mathrm{Y}=\rho_{\mathrm{yx} 1} \mathrm{X}_{1}+\rho_{\mathrm{y} \times 2} \mathrm{X}_{2}+\rho_{y x 4} \mathrm{X}_{4}+\rho_{y \varepsilon_{1}} \operatorname{dan} \mathrm{R}^{2}{ }_{\mathrm{yx} 4 \times 3}$

$=0,215 \mathrm{X}_{1}+0,350 \mathrm{X}_{2}+0,303 \mathrm{X}_{4}+0.360 \varepsilon \operatorname{dan} \mathrm{R}_{\mathrm{yx} \times 43}^{2}=0.32$

\section{PENUTUP}

Hipotesis penelitian yang berbunyi "pengorganisasi, pelaksanaan dan pengawasan berkontribusi secara simultan dan signifikan terhadap efektivitas pelayanan retribusi persampahan." Bahwa tidak semua variabel yang diterima, karena berdasarkan pengujian koefisien jalur hanya koefisien jalur X2 terhadap Y, X3 terhadap Y dan $\mathrm{X} 4$ terhadap $\mathrm{Y}$ yang secara statistik signifikan. Sedangkan koefisien jalur X1 terhadap $Y$ tidak signifikan. Dengan demikian hasil temuan analisis ini memberikan informasi, bahwa pengorganisasian (X2), pelaksanaan (X3) dan pengawasan (X4) berkontribusi secara simultan dan signifikan terhadap efektivitas pelayanan retribusi sampah (Y), besarnya diterangkan sebagai berikut:

Besarnya kontribusi pengorganisasian (X2) yang secara langsung mempengaruhi efektivitas pelayanan retribusi sampah (Y) adalah $0.215^{2}$ x $100 \%=4,622 \%$. Besarnya kontribusi pelaksanaan (X3) yang secara langsung mempengaruhi efektivitas pelayanan retribusi sampah $(\mathrm{Y})$ adalah $0.350^{2} \times 100 \%=12,25 \%$. Besarnya kontribusi pengawasan (X4) yang secara langsung mempengaruhi efektivitas pelayanan retribusi sampah (Y) adalah $0.303^{2} \times 100 \%=9,189 \%$.

\section{DAFTAR PUSTAKA}

A.S. Moenir, (2010). Manajemen Pelayanan Umum di Indonesia. Jakarta: PT Bumi Aksara.

Agung, Kurniawan 2005. Transformasi Pelayanan Publik. Yogyakarta: Pembaharuan.

Agung, Kurniawan 2005. Transformasi Pelayanan Publik. Yogyakarta: Pembaharuan.

Bastian, Indra dan Soepriyanto. 2002. "Sistem Akuntansi Sektor Publik". Salemba Empat. Jakarta.

Bintoro Tjokroamidjojo, Pengantar Administrasi pembangunan, LP3ES,. Jakarta, 1984.

Boediono. 2003. Pelayanan Prima Perpajakan. PT. Rineka Cipta: Jakarta.

Davey, K.J, 1988. Pembiayaan Pemerintah Daerah. Jakarta : PT. Gramedia.

Dendawijaya, Lukman. 2006. "Manajemen Perbankan". Edisi Kedua. Bogor: Ghalia Indonesia.

Effendi, Onong Uchjana. 2001, Ilmu Komunikasi Teori dan Praktek. Bandung : PT Remaja Rosdakarya.

Handayaningrat, Soewarno.1981. Pengantar Studi Ilmu Administrasi dan. Manajemen. Jakarta : CV Hajimasagung.

Handoko, T. Hani. 1986. Manajemen Edisi 2. BEFE. Yogyakarta.

Hardiansyah.2011. Kualitas Pelayanan Publik. Yogyakarta: Gava Media. 
Hasibuan S.P Malayu. 2014. Manajemen Sumber Daya Manusia. Jakarta: Bumi. Aksara.

Husni Thamrin, 2013, Hukum Pelayanan Publik di Indonesia, Yogyakarta.

Irwan Soehartono, Metode Penelitian Sosial, Suatu Teknik Bidang Kesejahteraan Sosial dan Ilmu Sosial Lainnya, Remaja Rosda Karya, Bandung, 2004.

Juliantara, Dadang. 2005. Peningkatan Kapasitas Pemerintah Daerah dalam. Pelayanan Publik. Yogyakarta: Pembaruan.

LAN RI,.Sistem Administrasi Negara Repoblik Indonesia. Gunung agung, Jakarta,1996.

Lewis. Sharon L. Dirksen. Shannon R, Heitkemper. Margaret M., Buncher. Linda., Camera. Medical Surgical Management of Clinical Problems, Eighth Edition volume: 2. United States of America: ELSEVIER MOSBY.

Mc Master, James, 1991. Urban Financial Management A Training Manual, The International Bank for Reconstruction and Development / The Word Bank 1818 H Street, N.W. Washington, D.C. 2043, USA.

Moenir. 2002. Maanajemen Pelayanan Umum di Indonesia. Jakarta: PT. Bumi.

Pabundu, Tika. 2008, Budaya Organisasi dan Peningkatan Kinerja Perusahaan.: Bumi. Aksara.

Pasolong, Harbani, 2007, Teori Administrasi Publik, Alfabeta, Bandung.

Pasolong, Harbani. 2010. Teori Administrasi Publik, Alfabeta, Bandung.
Ratminto

$\&$

Atik

Septi Winarsih. 2005.Manajemen

Pelayanan. Yogyakarta: Pustaka Pelajar.

Sedarmayanti.2009. Reformasi Administrasi Publik, Reformasi Birokrasi, dan Kepemimpinan Masa Depan(Mewujudkan Pelayanan Prima dan Kepemerintahan yang Baik). Bandung : Refika Aditama Sinambela, Lijan Poltak. Dkk. 2011 .Reformasi Pelayanan Publik. Jakarta:Bumi Aksara Sinambela,Lijan Poltak.Dkk. 2010. Reformasi Pelayanan Publik. Jakarta:Bumi Aksara.

Siagian, Sondang P, 2003. Teori dan Praktek Kepemimpinan. PT Rineka Cipta. Jakarta.

Siahaan, Marihot Pahala. Pajak Daerah dan Retribusi Daerah, Jakarta : PT Raja Grafindo . 2016.

Singarimbun, Masri. (2003). Metode Penelitian Survey. Jakarta: LP3ES.

Suandy, Erly. 2011. Hukum Pajak, Edisi 5, Jakarta: Salemba Empat.

Suriadinata. 2003. Kajian Tentang Keuangan Daerah. PT. Gramedia Jakarta.

Thoha, Miftah. 2008. Ilmu Administrasi Publik Kontemporer. Jakarta : Kencana. 


\section{BIOGRAFI PENULIS}

\begin{tabular}{|l|l||}
\hline & Vidi Adhitama merupakan Mahasiswa Pascasarjana pada Program Studi Ilmu \\
Administrasi, di bawah bimbingan Dr. H. Lalan Soeherlan S., M.Si dan Dr. H. Aceng \\
Jarkasih, M.Si dengan penelitian yang berjudul Pengaruh Perencanaan, \\
Pengorganisasian, Pelaksanaan dan Pengawasan terhadap Efektivitas Pelayanan \\
Sampah yang dilakukan pada Dinas Lingkungan Hidup Kabupaten Majalengka. \\
e-mail: -
\end{tabular}

